\title{
Concepts And Importance of Strategic Innovation in SMEs: Evidence from Serbia
}

\author{
UDC: 005.342:334.7(497.11) \\ 005.52:005.33 \\ DOI: 10.7595/management.fon.2015.0030
}

This paper aims to define a concept of strategic innovation given the impact it has on competitiveness, creation of growth strategies, new product categories and business models, as well as on changing the rules of the game on the existing market. In this sense, companies have to strategically redefine their business, to define new ways of competing in order to offer new value for consumers, stakeholders and companies themselves. If companies want to be successful they have to discover and exploit new strategic positions that emerge from time to time as industry evolves. Supporting this, the paper presents strategic elements of the National Innovation System (NIS), which can significantly contribute to Small and Medium-sized Enterprises (SMEs) to boost their business and to increase their competitiveness and innovativeness. Starting from the strategic positioning map, the paper gives some of the possible answers to the question of how SMEs in Serbia can improve their business, i.e., how the NIS can influence SMEs in terms of increasing business success.

Keywords: Strategic Innovation, Competitive advantage, NIS, SMEs

\section{Introduction}

The studies show that companies cannot rely only on the effectiveness improvement and cost cutting if they strive to remain competitive. Competitive advantage gained on the basis of operational effectiveness is shortlived, so companies that try to improve their performance should focus on the revenue growth (Tse, 2013). Therefore, companies' strategic redefinition of business, definition of new game rules or new ways of competing, becomes a necessity if they want to offer new value for consumers, stakeholders and themselves.

In today's rapidly changing economic environment innovation becomes a necessity, not only through new product or service development, but also through finding new business models, which often implies changing the rules of the game (Afuah, 2009). Studies show that companies who prioritize innovation are also those with the highest increase in turnover. Some $79 \%$ of companies that introduced at least one innovation since 2011 experienced an increase in their turnover by more than $25 \%$ by 2014 (European Commission, 2015). Competitive advantage is not just a function of how well a company plays by the existing rules of the game. It also depends on the company's capability to break those rules (Govindarajan \& Gupta, 2001). Breaking the rules of the game means that the company can strategically redefine its business and play an altogether different game in order to succeed on the long-term basis (Markides, 1997).

With the intention to acquire a greater positive impact, individuals, groups and organizations across all sectors of society tend to enter the market with bigger ideas. Being different and making difference are key drivers to business success whether developing a new product or service, creating a new HR program, improving finance procedures, introducing a new fundraising campaign or launching a new business (Kaplan, 2012). Regarding that, as a solution for breaking the rules of the game, bigger ideas, sustainable growth and profitability, Govindarajan and Trimble (2005) suggested strategic innovation. 


\section{Theoretical framework - understanding the strategic innovation}

One of the fundamental questions of innovation management refers to the strategic decision making in the field of development of new products, services, processes, organization, marketing, etc. (in accordance with Oslo Manual (2005)). These strategic decisions should make balance between companies' ability and opportunities that exist in the environment so as to achieve long-term business objectives. Regarding that, innovation strategy defining represents a key element of successful innovation management in the company (Stošić, 2013).

Lately, a large number of companies added innovation as one of the fundamental values in their mission (Johnston Jr. \& J. Douglas, 2013). Also, innovation strategy should support business strategy, where it acts as a mediator between the company and its environment in the innovation area. Often, it represents a key step for the company's entry on the existing market, however, also for gaining competitive advantage. Companies are constantly in a position to make strategic decisions within the innovation portfolio, primarily in terms of defining the priorities of innovation projects, and establishing innovative competence. Thus, innovation strategy should be synchronized with the technological, marketing, manufacturing and other functional strategies, as well as the strategy of intellectual property (Stošić, 2013).

Innovation strategy is based on the business model and technology of the companies. This means that successful companies combine technological change with the change of business model for the successful implementation of innovation (Epstein, Davila, \& Shelton, 2005).

It is very difficult for any company to successfully attack the established industry leaders or to successfully enter a new market where established players exist and not to rely on the benefit of new technological innovation. The strategy that appears to improve the success rate in those situations is the strategy of breaking the rule, i.e., the strategic innovation (Markides, 1997).

Strategic innovation represents a holistic, systematic approach focused on generating beyond incremental, breakthrough or discontinuous innovations. Only an intentional, repeatable process that creates a significant difference in the value delivered to consumers, customers, partners and other companies can be assumed as strategic innovation. It can be said that strategic innovation is a fundamentally different way of competing in an existing business (Charitou \& Markides, 2003), which can aid continuous innovation, avoiding the danger of going along with what may appear to be best practices (Prince, Barrett, \& Oborn, 2014).

Kaplan (2012), in his work, named the process of changing the game as leapfrogging. In fact, leapfrogging is about creating something new or doing something radically different that produces a significant leap forward. If individuals, groups or organizations prefer to become the new leaders of the future they have to leapfrog old ways of doing things (Kaplan, 2012).

New game activities can be performed at all stages of a value chain in one business system (Govindarajan \& Gupta, 2001; Afuah, 2009). Consequently, there are three main questions on which strategic innovators have to give answers if they want their rules to be the winning rules (Figure 1). Those questions are: "How can we make the value chain much more efficient?" "How can we transform the value the customers receive?" and "How do we expand the market size?" (Govindarajan \& Gupta, 2001). 


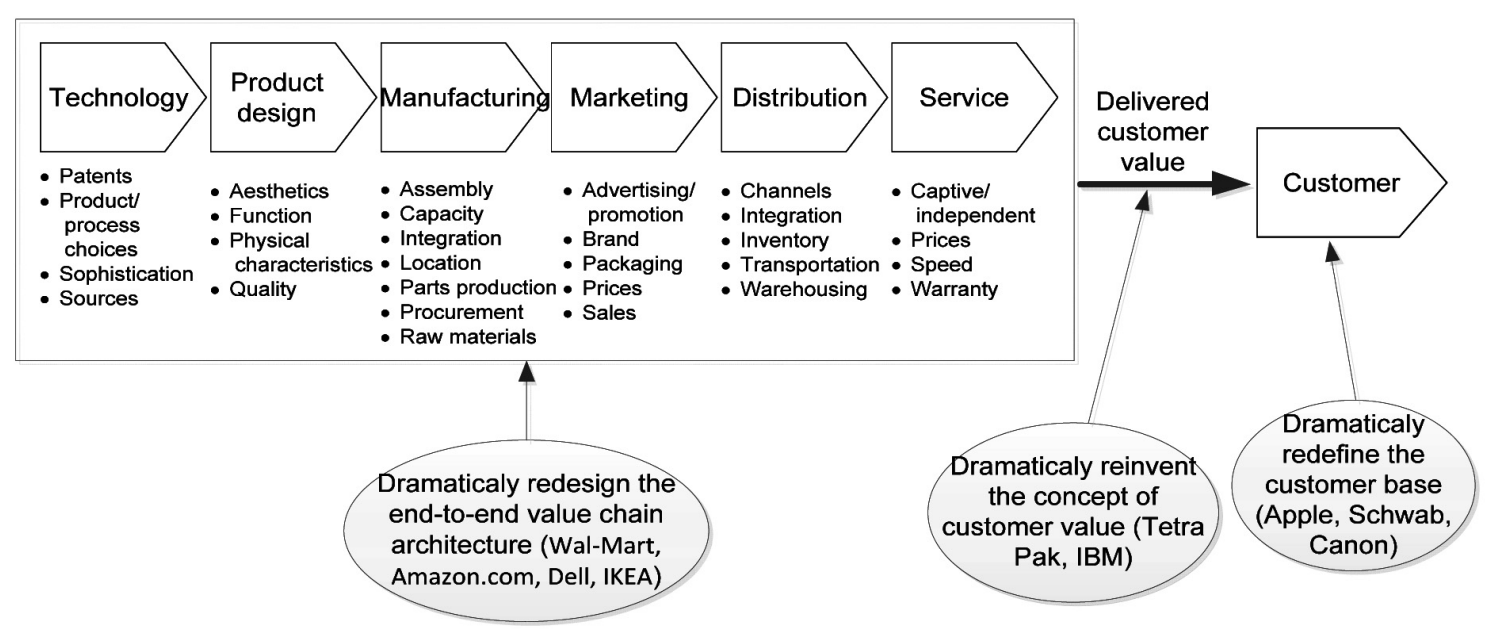

Figure 1: Areas for Changing the Rules of the Game (adapted from (Govindarajan \& Gupta, 2001; Afuah, 2009))

In accordance with Figure 2, dramatic redesign of the end-to-end value chain architecture can be accomplished improving the efficiency of the end-to-end value chain. For example, IKEA uses standardization by making one type of a product, which enables efficient transportation. Dramatic reinvention of the concept of customer value is related to changing the value that customers receive. For example, in addition to selling hardware, the IBM moved into supplying total business solutions. A dramatic redefinition of the customer base is related to expanding the size of the market. For example, at the time when computers were used only in corporations and other institutions, Apple made personal computers for individuals.

Therefore, a necessary requirement for becoming a strategic innovator is to identify gaps before everybody else does. Gaps imply: (1) new, emerging customer segments or existing customer segments that other competitors have neglected; (2) new, emerging customer needs or existing customer needs not served well by other competitors; and (3) new ways of producing, delivering, or distributing the existing or new products or services to the existing or new customer segments (Markides, 1997).

\section{Typology of strategic innovation}

A very important factor for defining the innovation strategy is a company competence, concerning the existing structure and knowledge. The innovation strategy and the company's competence are related to the extent that some authors indicate strategy as the architecture that builds competence. The results of empirical research in this area show that the degree and nature of innovativeness are in close relation to the choice of strategy of the innovation leader or follower. Companies that choose the first strategy mostly develop product innovation, while others mostly initiate process innovation (Stošić, 2013).

Having in mind the innovation matrix, companies focus their resources in selected segments, and thus create a portfolio of investments. Depending on the position of investment in the matrix, two types of innovation strategy can be recognized (Epstein, Davila, \& Shelton, 2005)

- Playing to win (PTW) and

- Playing not to lose (PNTL).

The "Playing-to-win" strategy is a strategy of the innovation leader that, predominantly, relies on semi-radical innovations - the company invests in new technology or business model in order to be ahead of competitors. The leadership position is achieved on the basis of repetition of different types of innovation: incremental, semi-radical and radical (e.g., Amazon.com, Apple). In cases where the competitive environment is very uncertain, and where high internal constraints exist, companies opt for the "Playing not to lose" strategy (e.g., Johnson \& Johnson, Hyundai). The PNTL strategy typically involves more incremental innovations, in order to maintain the company in the existing environment, moving slowly and with lower risk (Epstein, Davila, \& Shelton, 2005). 
Also, the strategy of the innovation leader and follower can be seen as proactive and reactive (Urban \& Hauser, 1993). A proactive strategy is a strategy of the innovation leader - companies seek to predict and anticipate changes in the environment and thus to seize the opportunities. A reactive strategy is a strategy of the innovation follower - companies respond to the customers demand and needs and to competitors' activity.

In addition, literature on strategic innovation makes a distinction between incremental strategic innovation and disruptive strategic innovation (Kataria, 2013). When it comes to incremental ones, value improvements are made on the existing customers and markets, which make them innovation followers, while organizations engaging in disruptive strategic innovation compete in such a way that the newly developed markets do not contain any competitors yet and competitive advantage is therefore automatically created, which make them innovation leaders.

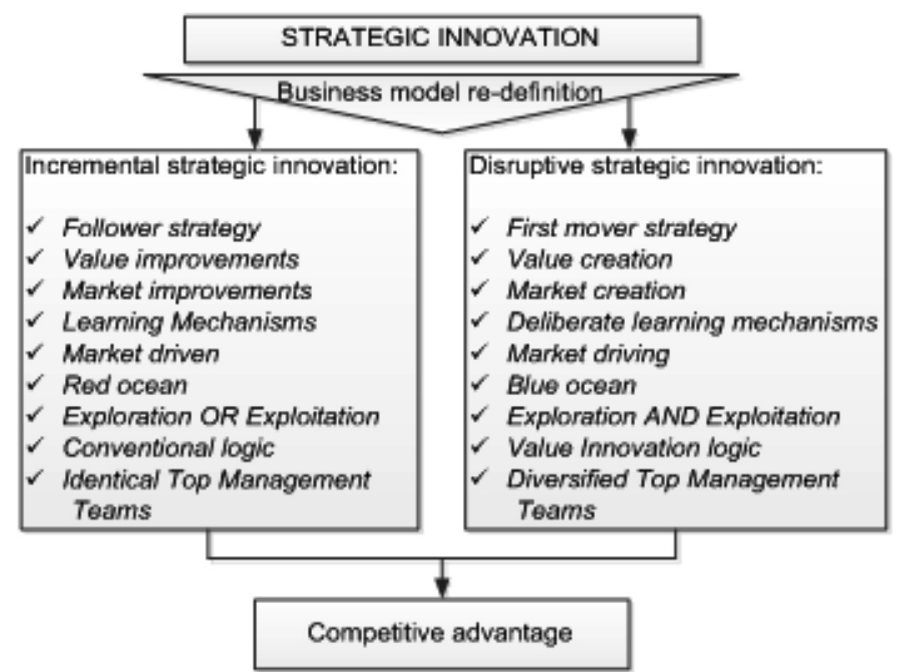

Figure 2: Strategic innovation typology (adapted from (Kataria, 2013))

The disruptive strategic innovation is evidently a more aggressive strategy for creating competitive advantage then the incremental one. Nevertheless, incremental strategic innovation is also aimed at creating competitive advantage but without disrupting the existing market. Thus, regarding typology of strategic innovation, the most frequent case is that innovation leaders engage the PTW strategy, proactive strategy or disruptive strategic innovation, while innovation followers engage the PNTL strategy, reactive strategy or incremental strategic innovation.

\section{The role of National innovation system in strategic innovation}

Concepts and policy approaches to innovation have changed considerably in the past years. Until recently, large companies were considered to be the main driving forces of growth and innovation. Nowadays, the interest has shifted to SMEs and networks of firms. Still, SMEs usually face more barriers than large companies. Thus, if SMEs want to overcome such barriers they have to rely more on external resources and partners (Tödtling \& Kaufmann, 2002).

It is for this reason that the paper presents some of the ways in which the National Innovation system can strategically support or help companies to improve their innovativeness. The NIS should have significant influence on successful realization of innovation. In accordance with the strategic positioning map (Markides, 1997), the paper tries to give some of the possible answers on the question how SMEs in Serbia can improve their business, i.e., what the NIS should do to help SMEs to be more successful.

Generally speaking, strategy (business, market, technology) can be defined as a component that connects the company and its environment. When it comes to the innovation strategy, two powerful factors from the environment can be identified (Stošić, 2013): 
- The National innovation system (NIS), in which the company is incorporated and in which it acts. The NIS can be defined as a complex network of companies, universities, research and development institutes, professional associations, financial institutions, educational and information infrastructure, state agencies and public resources, for generation, diffusion and application of scientific and technological knowledge in a particular country (OECD; Eurostat, 2005).

- The position of the company compared to the competitive environment.

Small and medium-sized enterprises and entrepreneurs are usually the most efficient segment of the economy. Their main contribution is reflected in the increase of employment, gross value added and income, which is why they are considered to be the main driver of growth and development of the national economy. Particularly important is their role in the transition countries that are facing the problems of high unemployment, low level of economic activity, lack of competition and lack of investment and wher large inefficient public enterprises still operate (Erić, Beraha, Đuričin, Kecman, \& Jakišić, 2012). SMEs are a particular target for innovation policy. One of the reasons is that they are facing big constraints regarding innovation or commercialization of innovations. Some $63 \%$ of companies with between 1 and 9 employees declare that they have introduced at least one innovation since 2011, in comparison with $85 \%$ of companies with $500 \mathrm{em}$ ployees or more. Some $71 \%$ of companies with between 1 and 9 employees encountered difficulties commercializing their innovations due to a lack of financial resources, compared to $48 \%$ of companies with 500 employees or more (European Commission, 2015).

Due to the importance of the SME sector in creating economic growth, both developed and developing countries are very interested in finding ways to stimulate SMEs in realizing innovations. Speaking of Serbia, SMEs represent the backbone of the economy. They constitute $99.8 \%$ of the total of active companies, employing approximately two thirds of employees in the non-financial sector and participate with a rate of about $30 \%$ in the formation of the GDP. The entrepreneurial sector of Serbia in 2013 included 315,412 companies, representing $99.8 \%$ of the total number of companies $(315,906)$ (Figure 3$)$. The SMEs generate $64.9 \%$ of employment in the non-financial sector by engaging 768,550 workers and $64.3 \%$ of turnover (NARR, 2014).

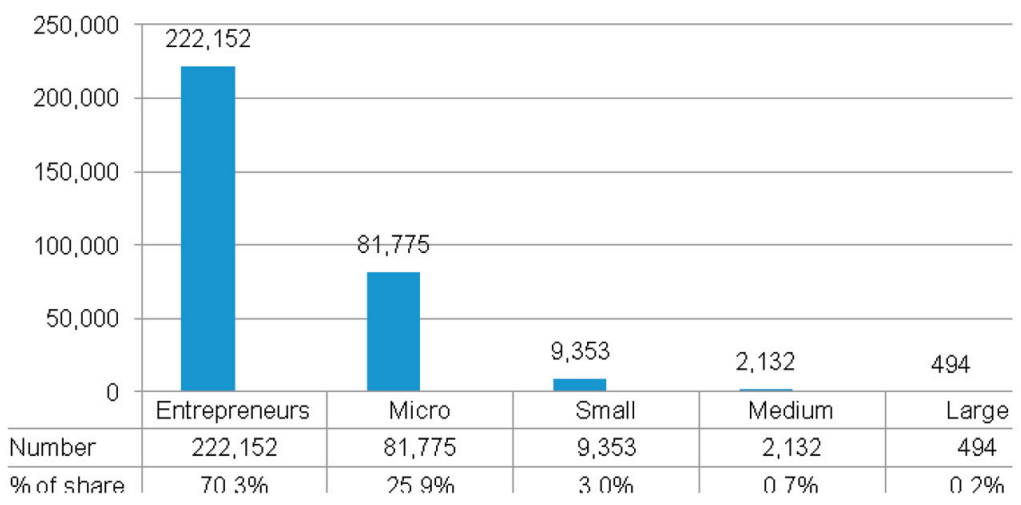

Figure 3: Number of business entities

Regardless of the global market, a large number of the innovation activities of enterprises is carried out and is linked to the national environment. Therefore, the impact of NIS factors is dominant, even when it comes to big companies. There are a lot of different incentives that the NIS can provide or enable in order to encourage SMEs to be more innovative. Innovation institutions, infrastructure, laws, strategies, different programmes are some of the mechanisms that can help SMEs overcome problems they are faced with.

Cluster is one of the basic innovation infrastructure means whose purpose is to enhance regional competitiveness and to encourage innovation in companies. The key contributions of clusters to companies are related to greater innovation, more efficient employment, economic development and entrepreneurs' initiatives. Their strategic importance for SMEs can be seen through: lower operating expenses (purchase is made at the cluster level; decrease in inventories of materials due to relationships established with suppliers at the clus- 
ter level; agencies and enterprises for provision of specialized and common services, such as marketing, accounting, consulting, professional and other services); lower expenses of new product/service development, diffusion of technology, exit to foreign markets, expansion of markets and opportunities for new business connections, possibility of a larger investment and development projects in the region, access to funds, soft loans, etc. According to the Catalogue of clusters in Serbia (2012), there are 40 clusters in Serbia. The increasing trend in the number of clusters in Serbia proves the need for clusterization in the SME sector.

Also, some types of innovation infrastructure important for the improvement of innovation and therefore strategic business of companies are Business Technology Incubators and Science and Technology Parks. The main idea of Business technology incubators, according to the Law on innovation activity (2013), is making available, for a fee, the office space, administrative, technical and other services to newly established companies or innovation organizations, maximum five years from their establishment. In Serbia, there are currently 24 incubators. One of the well-known is the Business Technology Incubator of Technical Faculties which comprises 51 SMEs and within which 40 innovations and 10 patents are developed. The aim of this type of innovation infrastructure is to create instruments for supporting young and educated people allowing them to start and develop their own business; to create conditions for direct commercialization of scientific research; to create new SMEs in the field of high technology (http://www.bitf.rs/cms/item/about/sr.html).

Similarly, a very important strategic factor for the improvement of companies' innovativeness and competitiveness is the Science and Technology Park. The aim of these parks is to give infrastructural and professional support to innovative companies for the purpose of their linking and faster implementation of new technologies, development and placement of new products and services, along with rapid technological development of the country (Law on Innovation, Official Gazette RS, No. 110/05, 18/10 and 55/13). One of the examples of this innovation infrastructure is the Zvezdara Science and Technology Park that started this year.

Consequently, there is a number of ways the NIS can contribute to companies to strategically improve their business. Knowing that many SMEs in Serbia operate with negative business results, there is a need to introduceg mechanisms that would help such companies in order not to go bankrupt. One such mechanism is The Law on consensual financial restructuring of companies, resulting from the need to overcome financial difficulties, i.e., insolvency of companies. Financial restructuring is being implemented voluntary, with the consent of creditors and debtors, with the necessary presence of the mediator, in this case, the Chamber of Commerce. The aim is to create the best solution through joint efforts redefining the relationship between companies and creditors, which are primarily banks, and the Chamber of Commerce as an institutional intermediary (Andrić, Radulović, Stefanović, Brežančić, Johnson, \& Nedić, 2014).

Conslusion

Strategic innovation represents a very important factor that companies should have within their business, and which should have a significant impact on improving the competitiveness of companies. When it comes to companies (primarily SMEs) in Serbia, great attention should be paid to the creation of such environment that will contribute to increasing of innovativeness, employment, investments, as well as strengthening of the industrial sector.

Some of the key recommendations which are related to the creation of such environment, favourable for the proper company development, refer to the establishment of a well-rounded incentive system of company development in the growth and development phase, based on the best practices of highly developed countries; encouraging talented people with a clear vision to start their own business; change of the previous method of financing; provision of advice related to venture financing, strategic planning, support for integration into supply chains of large companies, internationalization of companies, etc; development of regulatory reforms directed toward removing obstacles for foundation of new companies, as well as creation of favourable conditions for growth of dynamic companies (NARR, 2014).

Engaging strategic innovation, companies should take advantage of the aforementioned incentives with the establishment of "new game rules and market barriers", along with new ways of doing business, aiming at gaining the position of innovation and market leader. Thus, companies can change the rules of the existing game on the market using the elements of the NIS and in that way identify gaps before everybody else does. 


\section{REFERENCES}

[1] Afuah, A. (2009). Strategic Innovation: New Game Strategies for Competitive Advantage. Routledge.

[2] Andrić, L., Radulović, B., Stefanović, M., Brežančić, M., Johnson, G. W., \& Nedić, B. (2014). Vodič kroz sporazumno finansijsko restrukturiranje privrednih društava. Partneri za demokratske promene Srbija.

[3] Charitou, C., \& Markides, C. (2003). Responses to Disruptive Strategic Innovation. MIT Sloan Management Review , 44 (2), 55-63.

[4] Epstein, M., Davila, T., \& Shelton, R. (2005). Driving Success: How You Innovate Determines What You Innovate.

[5] Erić, D. D., Beraha, A. I., \uričin, O. S., Kecman, —. N., \& Jakišić, B. B. (2012). Finansiranje malih i srednjih preduzeća u srbiji. Institut ekonomskih nauka, Privredna komora Srbije.

[6] European Commission. (2015, September 30). Innovation. From Internal market, Industry, Enterpreneurship and SMEs.

[7] Freeman, C. (1987). Technology and Economic Performance: Lessons from Japan. London: Pinter.

[8] Gebauer, H., Worch, H., \& Truffer, B. (2012). Absorptive capacity, learning processes and combinative capabilities as determinants of strategic innovation. European Management Journal , 30 (1), 57-73.

[9] Govindarajan, V., \& Euchner, J. (2010). Making strategic innovation work: an interview with Vijay Govindarajan. Research Technology Management , 53, 15-20.

[10] Govindarajan, V., \& Gupta, A. K. (2001). Strategic innovation: A conceptual road map. Business Horizons.

[11] Govindarajan, V., \& Trimble, C. (2005). 10 Rules for Strategic Innovators. Harvard University Press.

[12] Johnston Jr., R. E., \& J. Douglas, B. (2013). The Power of Strategy Innovation: A New Way of Linking Creativity and Strategic Planning to Discover Great Business Opportunities. New York: American Management Association.

[13] Kaplan, S. (2012). Leapfrogging: Harness the Power of Surprise for Business Breakthroughs. BerrettKoehler Publishers.

[14] Kataria, S. (2013). Strategic innovation: a review and a theoretical framework.

[15] Law on Innovation, Official Gazette RS, No. 110/05, 18/10 and 55/13.

[16] Markides, C. (1997). Strategic Innovation. Sloan Management Review/Spring , 38, 9-24.

[17] NARR. (2014). Izveštaj o malim i srednjim preduzećima i preduzetništvu za 2013. godinu. Beograd: Ministarstvo privrede, Nacionalna agencija za regionalni razvoj.

[18] OECD; Eurostat. (2005). Oslo Manual - Guidelines for collecting and interpreting innovation data (3rd ed.). Joint Publication.

[19] Palmer, D., \& Kaplan, S. (2013). A Framework for Strategic Innovation - Blending strategy and creative exploration to discover future business opportunities.

[20] Prince, K., Barrett, M., \& Oborn, E. (2014). Dialogical strategies for orchestrating strategic innovation networks: The case of the Internet of Things. Information and Organization , 24 (2), 106-127.

[21] Stošić, B. (2013). Innovation Management - Innovation projects, models and Methods. Belgrade: Faculty of Organizational Sciences.

[22] The Cluster Council. (2012). Catalogue of clusters in Serbia. Klaster DIŠ NIŠ.

[23] Tidd, J., Bessant, J., \& Pavitt, J. (2011). Managing innovation. John Wiley \& Sons.Tödtling, F., \& Kaufmann, A. (2002). SMEs in regional innovation systems and the role of innovation support-the case of upper Austria. The Journal of Technology Transfer , 27 (1), 15-26.

[25] Tse, T. (2013). Paradox resolution: A means to achieve strategic innovation. European Management Journal , 31 (6), 682-696.

[26] Urban, G. L., \& Hauser, J. R. (1993). Design and Marketing of New Products. Prentice Hall. 


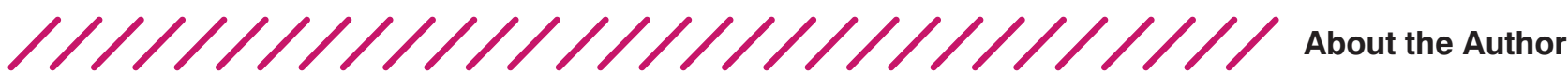

\section{Radul Milutinović University of Belgrade, Faculty of Organizational Sciences, Serbia}

Radul Milutinović is Teaching Assistant at the Innovation Management study course at the Faculty of Organizational Sciences, University of Belgrade, Serbia. He holds a BSc degree in the field of Management and a MSc degree in the areas of Project and Investment Management. At present, he is a PhD candidate. His primary areas of research are Innovation Management, Innovation Project Management and Intellectual Property. He has published numerous publications at national and international conferences and journals.

\section{Biljana Stošić \\ University of Belgrade, Faculty of Organizational Sciences, Serbia}

Biljana Stošić is Professor of Innovation Management at the Faculty of Organizational Sciences, University of Belgrade, Serbia. She holds a BSc degree in the field of Information Systems and MSc and PhD degrees in the areas of Innovation and

Technology Management. Her research interest is oriented towards Innovation Management, Project Management and Intellectual Property. She has authored and coauthored numerous publications at national and international conferences and journals.

She is the author of Innovations in Technology - Theoretical Basis and Methods of Support; Innovation Management - Expert Systems, Models and Methods; Innovation Management - Innovation projects, Models and Methods.

\section{University of Belgrade, Faculty of Organizational Sciences, Serbia}

Marko Mihić is an Assistant Professor at the Faculty of Organizational Sciences, Management Department. His research interest includes management, project management, strategic management and change management. He has published 7 monographs and over 120 peer-reviewed papers. As an expert consultant, he has worked extensively for the Serbian government institutions, as well as for several leading national and multinational companies and investors in Serbia.
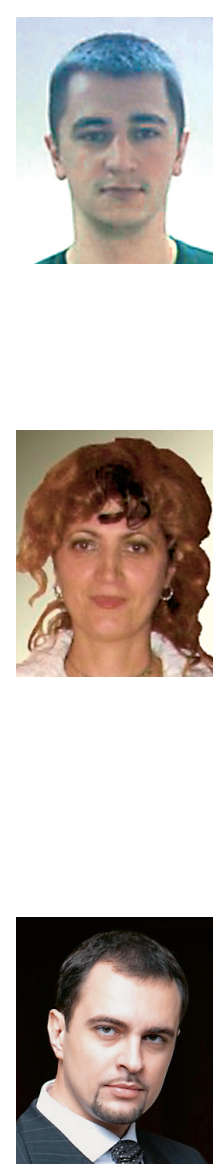